\title{
Fuel utilization by cells of the immune system
}

\author{
BY PHILIP C. CALDER \\ Department of Biochemistry, University of Oxford, South Parks Road, Oxford OX1 3QU
}

\section{Utilisation des substrats énergétiques par les cellules du système immunitaire}

\begin{abstract}
RÉSUMÉ
Les mesures des activités maximales des enzymes-clés dans les voie d'utilisation des glucides, lipides et acides aminés indiquent que les lymphocytes et les macrophages ont la possibilité d'utiliser le glucose, le glycogène, les acides gras, les corps cétoniques et la glutamine comme substrats énergétiques; ces cellules possèdent également certaines enzymes de la gluconéogenèse, de la voie de pentose phosphate, de la synthèse des acides gras et de la synthèse des corps cétoniques. L'activité de l'hexokinase (EC 2.7.1.1) est plus importante que celle de la phosphorylase du glycogène ( $E C$ 2.4.1.1), ce qui suggère que le glycogène endogène est un substrat énergétique moins important que le glucose exogène. Les activités de la pyruvate kinase ( $E C$ 2.7.1.40) et de la lactate déshydrogénase ( $E C$ 1.1.1.27) sont élevées, ce qui indique l'importance de la glycolyse du glucose en anaérobie dans ces cellules. L'activité de la glutaminase ( $E C$ 3.5.1.2) est très élevée dans les lymphocytes et les macrophages. La pyruvate déshydrogénase $(E C$ 1.2.4.1) et les enzymes du cycle de Krebs sont présents, bien qu'il semble que ces cellules ne métabolisent pas le glucose en aérobie, que les acides gras ne sont pas un substrat énergétique important, et que la plus grande partie de la glutamine utilisée n'est pas totalement oxydée. Le glucose est utilisé à un taux élevé par les lymphocytes et les macrophages; le taux de l'utilisation du glucose est augmenté par la stimulation mitogénique des lymphocytes. La plus grande partie du glucose $(>90 \%$ dans certaines études) est convertie en lactate, bien qu'une certaine proportion ( $<20 \%$ dans la plupart des études) soit totalement oxydée. Les taux d'utilisation de la glutamine par les lymphocytes et les macrophages sont comparables ou supérieurs aux taux d'utilisation du glucose par ces cellules. La stimulation mitogénique des lymphocytes augmente significativement le taux de l'utilisation de la glutamine. Les principaux produits de l'utilisation de la glutamine sont le glutamate, l'aspartate et l'ammoniaque, mais l'alanine, le lactate, et le pyruvate sont également produits, et une partie de la glutamine ( $<10 \%$ dans la plupart des études) est totalement oxydée. Cette voie d'oxydation partielle de la glutamine a été appelée glutaminolyse. Un certain nombre de fonctions des cellules immunitaires testées in vitro dépendent de l'apport de glutamine.

Les lymphocytes et les macrophages sont capables d'utiliser toute une variété d'acides gras; une partie des acides gras utilisés est complètement oxydée, bien que la majeure partie soit incorporée dans des phospholipides (en particulier dans les lymphocytes) ou stockées comme triacylglycérols (en particulier dans les macrophages). Les acides gras, en particulier les acides gras insaturés, ont des fonctions immunomodulatoires. Les macrophages synthétisent et sécrètent de la lipoprotéine lipase ( $E C$ 3.1.1.34), ce qui
\end{abstract}


indique qu'ils ont la capacité d'hydrolyser les acides gras des triacylglycérols circulants. L'activité de la lipoprotéine lipase a récemment été rapportée dans des lymphocytes. Les corps cétoniques peuvent être utilisés (et oxydés) par les lymphocytes, mais apparemment pas par les macrophages. Selon plusieurs rapports, les acides gras n'affectent pas l'utilisation du glucose, l'utilisation de la glutamine, ou la production de lactate par les lymphocytes ou les macrophages. De même, les corps cétoniques ne suppriment pas l'utilisation du glucose ou la production de lactate par les lymphocytes. Les interactions entre le glucose et la glutamine semblent être complexes; certaines études rapportent que chaque substrat énergétique augmente le taux d'utilisation de l'autre, tandis que selon d'autres études chaque substrat peut diminuer le taux d'utilisation de l'autre.

\section{CELLS OF THE IMMUNE SYSTEM}

Animals possess several barriers for protection against disease and infection. Some of these are present before exposure to infections, microbes or other foreign molecules and are not enhanced by such exposures. These are components of innate (or natural) immunity, and include phagocytic cells in the blood and in tissues, a class of lymphocytes called natural killer cells and various blood-borne chemicals. Other defence mechanisms are induced or stimulated by exposure to foreign substances, are specific for distinct macromolecules and increase in magnitude with each successive exposure to a particular macromolecule. These mechanisms constitute specific (or acquired) immunity.

The specific immune system has developed to include a number of cooperative functions between effector cells and molecules, allowing amplification of immune responses. Specific immune responses are classified into two types, humoral and cell-mediated immunity, based on the components of the immune system that are involved in the response. Humoral immunity is mediated by antibodies released by B-lymphocytes into the bloodstream which are responsible for specific recognition and elimination of antigens. Cell-mediated immunity involves specific antigen recognition by T-lymphocytes. The cells of the immune system are normally present as circulating cells in blood and lymph, as anatomically defined collections in lymphoid organs (thymus, spleen, lymph nodes) or as scattered cells in virtually all tissues. The principal cells of the immune system are T- and B-lymphocytes, natural killer cells, mononuclear phagocytes and granulocytes.

\section{Lymphocytes}

Lymphocytes consist of distinct subsets, which are different in their functions and protein products, but are morphologically similar. B-lymphocytes mature in the bone marrow and are the only cells capable of producing antibodies. The antigen receptors of B-lymphocytes are membrane-bound antibodies. Interaction of antigens with these membrane-bound antibodies initiates the sequence of B-cell activation, which culminates in the development of effector cells that actively secrete antibody molecules.

The second major class of lymphocytes are T-lymphocytes, which arise in the bone marrow and then migrate to the thymus where they mature. T-lymphocytes are characterized by the presence of the T-cell receptor, and the associated CD3 complex, on their surface. The T-cell receptor and CD3 are the key molecules involved in specific 
antigen recognition by, and antigen-induced activation of, major histocompatibility complex-restricted T-lymphocytes. Several other proteins expressed on the surface of T-cells, collectively termed accessory molecules, also play important roles in antigen recognition by, and functional responses of, T-lymphocytes. As a consequence of binding their specific ligands on the surfaces of other cells, accessory molecules increase the strength of adhesion between a T-cell and an antigen-presenting cell, resulting in activation of the T-cell, while some accessory molecules may be involved in transducing biochemical signals to the interior of the T-cell. Once activated, the T-cell will proliferate and produce immunoregulatory cytokines, in particular interleukin (IL)-2.

\section{Mononuclear phagocytes}

Mononuclear phagocytes constitute the second major cell population of the immune system and consist of cells that have a common lineage, whose primary function is phagocytosis. Both monocytes and macrophages are components of the mononuclear phagocyte system. The precursors of these cells originate in the bone marrow, from which incompletely differentiated monocytes enter the peripheral blood. Monocytes are $10-20 \mu \mathrm{m}$ in diameter and have well-developed Golgi apparatus, numerous lysosomal granules, evenly distributed mitochondria and a single kidney-shaped nucleus; their half-life in the bloodstream is relatively short $(<70 \mathrm{~h})$. Once they have settled in a tissue (such as connective tissue, liver, lung or the peritoneal cavity), monocytes mature and become macrophages. Macrophages are larger than monocytes $(10-80 \mu \mathrm{m}$ in diameter) and have an oval-shaped nucleus, a cytoplasm containing numerous dense granules, endocytic vesicles, mitochondria and lysosomes and many pseudopodia extending from the cell surface. In contrast to the short half-life of monocytes, macrophages remain in tissues for many months, perhaps even years. Often they are named to designate specific locations; for example, in the central nervous system they are called microglia and in the vascular sinusoids of the liver they are called Kupffer cells. Macrophages sometimes remain relatively quiescent as resident cells; these are tissue macrophages that have not encountered foreign materials and have low functional activities. If they encounter foreign materials, such as micro-organisms, they differentiate further and become activated. The activation of macrophages involves multiple phenomena, but there is general agreement in categorizing these cells as inflammatory macrophages, which are high in secretory activity but do not possess microbicidal or tumouricidal activity, or activated macrophages, which are low in secretory activity but possess high activity in secreting reactive oxygen metabolites (the superoxide radical and $\mathrm{H}_{2} \mathrm{O}_{2}$ ) and have microbicidal and tumouricidal activity. Inflammatory macrophages are stimulated by non-specific inflammatory factors, whereas activated macrophages are stimulated by immunological factors via lymphocyte-derived products (i.e. cytokines). The terms stimulated or elicited are also used to describe inflammatory macrophages. As a result of the different developmental and environmental factors which prevail, macrophages at one site may become morphologically and functionally different from those at other sites. Mononuclear phagocytes are critical for natural immunity, but also play a part in specific immunity. Macrophages phagocytose foreign particles or injured or dead cells (such as senescent erythrocytes) and they secrete enzymes, reactive oxygen species, prostaglandins, cytokines and growth factors. These functions are all part of natural immunity. Macrophages can also behave as antigen-presenting cells, displaying foreign 
antigens on their cell surface for recognition by antigen-specific T-lymphocytes. They are activated by cytokines, which have been released from helper T-cells, and these enable macrophages to perform their phagocytic and degradative functions more effectively than unstimulated cells. Since they possess receptors for antibodies, macrophages also participate in the elimination of foreign antigens by humoral immune responses.

\section{MAXIMAL ACTIVITIES OF KEY ENZYMES OF PATHWAYS INVOLVED IN FUEL UTILIZATION}

One approach to obtaining information about the importance of different pathways of fuel utilization, and so of the importance of different fuels, is to measure the maximal activities of key enzymes in different pathways, each of which characterizes the use of a particular fuel. The quantitative value of this approach depends on the enzymes chosen; they must function only in one pathway and must catalyse non-equilibrium reactions. It must be emphasized that maximal enzyme activities indicate only the maximum potential for the utilization of a particular fuel and cannot determine whether a fuel is actually used in a given situation. The enzymes chosen as indicators of fluxes through pathways are hexokinase ( $E C$ 2.7.1.1; for glycolysis-from-glucose), glycogen phosphorylase ( $E C$ 2.4.1.1) and 6-phosphofructokinase (EC 2.7.1.11; for glycolysis-from-glycogen), oxoglutarate dehydrogenase ( $E C$ 1.2.4.2; for Krebs' cycle), carnitine palmitoyltransferase ( $E C$ 2.3.1.21; for fatty acid oxidation) and glutaminase $(E C$ 3.5.1.2; for glutamine utilization). These activities, as well as those of a number of other enzymes, have been measured in lymphocytes and macrophages (Table 1). The maximal activities of the indicator enzymes are in excess of the calculated fluxes through the pathways of glycolysis, Krebs' cycle, fatty acid $\beta$-oxidation and glutamine utilization (Ardawi \& Newsholme, 1985). Thus, the maximal activities of these indicator enzymes do not provide a quantitative assessment of the flux through the respective pathways.

Despite the inability to make precise quantitative assessments from enzyme activity data, the measurement of maximal enzyme activities gives an indication of the potential for a tissue or cell type to carry out various processes and can also provide information about the relative roles of different pathways. For example, the higher activity of hexokinase than of glycogen phosphorylase in lymphocytes and macrophages (Table 1) suggests that endogenous glycogen is a much less important fuel than exogenous glucose. This is supported by the observations that the activities of hexokinase and 6phosphofructokinase are similar (Table 1) and that the glycogen contents of lymphocytes and macrophages are low (Bustos \& Sobrino, 1989). The high activities of pyruvate kinase $(E C$ 2.7.1.40) and lactate dehydrogenase $(E C$ 1.1.1.27) are indicative of the importance of 'anaerobic' glycolysis-from-glucose in these cells (see p. 71). Lymphocytes and macrophages possess enzymes of the pentose phosphate pathway (Table 1), as might be expected for cells which carry out biosynthetic reactions (purine and pyrimidine syntheses use ribose-5-phosphate, a product of the pentose phosphate pathway) and display the respiratory burst (NADPH is produced by the pentose phosphate pathway). The enzymes of pyruvate oxidation and the Krebs' cycle are present in lymphocytes and macrophages, although it appears that these cells do not metabolize glucose 'aerobically' and that most of the glutamine they use is not fully oxidized (see p. 71). The enzymes of ketone-body utilization are found in lymphocytes and macrophages, indicating that these cells are able to use ketone bodies as energy sources. It should be noted, however, that 
Table 1. Maximal enzyme activities in lymphocytes and macrophages (Data taken from Curi et al. 1989a and Newsholme et al. 1989)

\begin{tabular}{|c|c|c|c|c|}
\hline \multirow[b]{3}{*}{ Enzyme } & \multirow[b]{3}{*}{$E C$ no. } & \multicolumn{3}{|c|}{ Enzyme activity (nmol/min per mg protein) } \\
\hline & & \multicolumn{2}{|c|}{ Lymphocytes } & \multirow{2}{*}{$\frac{\text { Macrophages }}{\text { Mouse peritoneal }}$} \\
\hline & & Rat lymph node & Human blood & \\
\hline \multicolumn{5}{|l|}{$\overline{\text { Glycolysis }}$} \\
\hline Hexokinase & 2.7.1.1 & $17 \cdot 3$ & $13 \cdot 8$ & 76 \\
\hline Glycogen phosphorylase & 2.4.1.1 & $3 \cdot 8$ & nd & $3 \cdot 0$ \\
\hline 6-Phosphofructokinase & 2.7 .1 .11 & 25.7 & $25 \cdot 7$ & $22 \cdot 3$ \\
\hline Pyruvate kinase & 2.7 .1 .40 & 403 & 103 & 447 \\
\hline Lactate dehydrogenase & 1.1.1.2 & 823 & nd & 764 \\
\hline \multicolumn{5}{|l|}{ Pentose phosphate pathway } \\
\hline Glucose-6-phosphate & & & & \\
\hline dehydrogenase & 1.1 .1 .49 & $17 \cdot 5$ & nd & $34 \cdot 5$ \\
\hline 6-Phosphogluconate & & & & \\
\hline dehydrogenase & 1.1.1.44 & $21 \cdot 1$ & nd & $23 \cdot 8$ \\
\hline \multicolumn{5}{|l|}{ Gluconeogenesis } \\
\hline Phosphoenolpyruvate & & & & \\
\hline carboxykinase & 4.1 .1 .49 & 4.9 & nd & 7.6 \\
\hline Pyruvate carboxylase & 6.4 .1 .1 & $2 \cdot 5$ & nd & 4.7 \\
\hline \multicolumn{5}{|l|}{ Krebs' cycle } \\
\hline Pyruvate dehydrogenase & 1.2.4.1 & $3 \cdot 3$ & nd & $3 \cdot 2$ \\
\hline Citrate synthase & 4.1.3.7 & $63 \cdot 7$ & 107 & 108 \\
\hline $\mathrm{NAD}^{+}$-linked isocitrate & & & & \\
\hline dehydrogenase & 1.1.1.41 & $6 \cdot 3$ & nd & $5 \cdot 8$ \\
\hline $\mathrm{NADP}^{+}$-linked isocitrate & & & & \\
\hline dehydrogenase & 1.1.1.42 & $26 \cdot 9$ & nd & $27 \cdot 4$ \\
\hline Oxoglutarate dehydrogenase & 1.2 .4 .2 & $5 \cdot 1$ & nd & $10 \cdot 1$ \\
\hline $\mathrm{NAD}^{+}$-linked malate & & & & \\
\hline dehydrogenase & 1.1.1.37 & 683 & nd & 452 \\
\hline \multicolumn{5}{|l|}{ Fatty acid synthesis } \\
\hline Acetyl-CoA carboxylase & 6.4 .1 .2 & $2 \cdot 7$ & nd & nd \\
\hline ATP-citrate lyase & 4.1 .3 .8 & $1 \cdot 1$ & nd & $1 \cdot 6$ \\
\hline $\mathrm{NADP}^{+}$-linked malate & & & & \\
\hline dehydrogenase & 1.1.1.82 & 3.5 & nd & $0 \cdot 001$ \\
\hline \multicolumn{5}{|l|}{ Ketone-body metabolism } \\
\hline HMGCoA synthase & 4.1 .3 .5 & 18.6 & nd & nd \\
\hline HMGCoA lyase & 4.1.3.4 & $5 \cdot 4$ & nd & nd \\
\hline Acetoacetyl-CoA thiolase & 2.3 .1 .9 & $27 \cdot 4$ & nd & $15 \cdot 5$ \\
\hline$\beta$-Hydroxybutyrate & & & & \\
\hline dehydrogenase & 1.1.1.61 & $4 \cdot 8$ & nd & $0 \cdot 17$ \\
\hline 3. Oxoacid-CoA transferase & 2.8 .3 .5 & $19 \cdot 9$ & nd & nd \\
\hline \multicolumn{5}{|l|}{ Fatty acid oxidation } \\
\hline Carnitine palmitoyltransferase & 2.3 .1 .21 & $0 \cdot 5$ & nd & 0.75 \\
\hline \multicolumn{5}{|l|}{ Amino acid metabolism } \\
\hline $\begin{array}{l}\text { Phosphate-dependent } \\
\text { olutaminase }\end{array}$ & 3512 & 39.4 & 37.5 & 152 \\
\hline Glutamate dehydrogenase & 1.4 .1 .2 & $34 \cdot 0$ & $71 \cdot 0$ & $98 \cdot 6$ \\
\hline Aspartate aminotransferase & 2.6 .1 .1 & $67 \cdot 4$ & nd & 118 \\
\hline Alanine aminotransferase & 2.6 .1 .2 & $10 \cdot 3$ & nd & $4 \cdot 4$ \\
\hline
\end{tabular}


Table 2. Glutaminase (EC 3.5.1.2) activities of lymphoid tissue (Data are taken from Ardawi \& Newsholme, 1985)

\begin{tabular}{|c|c|c|}
\hline Animal & Tissue & $\begin{array}{l}\text { Glutaminase activity } \\
\text { ( } \mu \mathrm{mol} / \mathrm{min} \text { per } \mathrm{g} \\
\text { wet weight })\end{array}$ \\
\hline Gerbil & Mesenteric lymph node & $5 \cdot 6$ \\
\hline Guinea-pig & Mesenteric lymph node & $6 \cdot 0$ \\
\hline Hamster & Mesenteric lymph node & 6.6 \\
\hline Mouse & Mesenteric lymph node & $9 \cdot 2$ \\
\hline Rabbit & Mesenteric lymph node & $4 \cdot 6$ \\
\hline \multirow[t]{5}{*}{ Rat } & Mesenteric lymph node & 8.7 \\
\hline & Thymus & $6 \cdot 0$ \\
\hline & Spleen & $6 \cdot 1$ \\
\hline & Peyer's patches & $10 \cdot 6$ \\
\hline & Bone marrow & $3 \cdot 7$ \\
\hline
\end{tabular}

Table 3. Glutaminase (EC 3.5.1.2) activities of lymphocytes and macrophages

\begin{tabular}{llcl}
\hline Animal & \multicolumn{1}{c}{ Cell } & $\begin{array}{c}\text { Glutaminase } \\
\text { activity }\end{array}$ & Reference \\
\hline \multirow{2}{*}{ Rat } & Lymph node lymphocytes & $6 \cdot 7^{*}$ & Keast \& Newsholme (1990) \\
& Splenocytes & $3 \cdot 9^{*}$ & \\
Man & Blood lymphocytes & $37 \cdot 5 \dagger$ & Ardawi (1988) \\
Rat & Lymph node lymphocytes & $39 \cdot 4 \dagger$ & Newsholme et al. (1986) \\
Mouse & Peritoneal macrophages & $150 \dagger$ & Newsholme et al. $(1986)$ \\
\hline
\end{tabular}

* $\mu \mathrm{mol} / \mathrm{min}$ per g dry wt.

$\dagger \mathrm{nmol} / \mathrm{min}$ per mg protein.

the activities of these enzymes are lower than those found in brain, heart and skeletal muscle, tissues in which ketone-body utilization is known to be important. In addition, the enzymes of ketone-body synthesis are found in lymphocytes; this is consistent with reports that these cells synthesize ketone bodies in vitro (Curi et al. 1989a,b). The first enzyme in the pathway of glutamine utilization is glutaminase:

$$
\text { Glutamine }+\mathrm{H}_{2} \mathrm{O} \longrightarrow \text { Glutamate }+\mathrm{NH}_{4}{ }^{+}
$$

The activity of glutaminase is high in all lymphoid tissues examined, including lymph nodes, spleen, thymus, Peyer's patches and bone marrow (Table 2), in lymphocytes isolated from rat lymph nodes, spleen and thymus and from human peripheral blood and in macrophages isolated from the mouse peritoneal cavity (Table 3). This suggests that the pathway of glutamine utilization is important in these cells (see p. 71). Glutaminase is located within the mitochondria of lymphocytes and macrophages (Curi et al. 1986). Interestingly, glutaminase activity in the mesenteric lymph node is increased by starvation and in the popliteal lymph node by an immunological challenge (Ardawi \& 
Newsholme, 1982). The maximal activity of carnitine palmitoyltransferase, the key enzyme of fatty acid oxidation, in lymphoid tissues, lymphocytes and macrophages is low compared with the activity in heart and soleus muscle and is low compared with the activities of hexokinase and glutaminase.

\section{UTILIZATION OF FUELS BY LYMPHOCYTES \\ AND MACROPHAGES}

Studies of fuel utilization can be made by measuring the respiratory exchange ratio (also known as the RQ) but the results are difficult to interpret and the investigation of the utilization of different forms of a particular type of fuel, for example carbohydrate, cannot be made. A more direct method for determining fuel utilization is to measure the changes in fuel concentration and in the concentrations of the products of metabolism. This approach has been used to investigate the utilization of glucose, glutamine, fatty acids and ketone bodies by lymphocytes and macrophages in vitro.

\section{Glucose}

It has been known for many years that lymphocytes and macrophages utilize glucose at a high rate (Karnovsky et al. 1970; Roos \& Loos, 1973) and until the important role of glutamine was identified (see below), glucose was considered to be the only fuel used to provide energy for cells of the immune system (Roos \& Loos, 1973; Hume et al. 1978). The rates of utilization of glucose by lymphocytes from a variety of sources and by mouse peritoneal macrophages are shown in Table 4. Mitogenic stimulation of lymphocytes increases both hexokinase activity (Brand, 1985) and the rate of glucose utilization (Table 4). In both resting and mitogen-stimulated lymphocytes and in resting macrophages most of the glucose utilized is converted to lactate, although some is completely oxidized (Table 4). The importance of glucose to these cells is indicated by the report that concanavalin A (Con A)-stimulated proliferation of rat thymocytes in vitro is dependent on glucose concentration over the physiological range (Hume et al. 1978).

\section{Glutamine}

The rates of glutamine utilization by resting lymphocytes and macrophages are high (Table 5) and are comparable with, or greater than, the rates of glucose utilization by these cells (Table 4). Mitogenic stimulation of lymphocytes markedly increases both glutaminase activity (Brand, 1985) and the rate of glutamine utilization (Table 5). The major products of glutamine metabolism are glutamate, aspartate and $\mathrm{NH}_{3}$, although alanine, lactate and pyruvate are also produced and some glutamine is completely oxidized (Table 5). The pathway of partial oxidation of glutamine to glutamate, aspartate and lactate has been termed glutaminolysis (McKeehan, 1982) and is shown in Fig. 1.

The studies of fuel utilization by lymphocytes and macrophages summarized in Tables 4 and 5 were performed using the cells in culture. It is possible that the high rates of utilization of glucose and glutamine and the limited oxidation of these substrates are in some way a result of the culture conditions. However, a study which measured the fluxes of fuels across the pig spleen before and after surgery (Deutz et al. 1992) largely supports 
Table 4. Utilization of glucose by lymphocytes and macrophages

\begin{tabular}{|c|c|c|c|c|c|}
\hline \multirow[b]{2}{*}{ Cell source } & \multirow[b]{2}{*}{ Con A } & \multirow{2}{*}{$\begin{array}{l}\text { Rate of glucose } \\
\text { utilization }\end{array}$} & \multicolumn{2}{|c|}{$\begin{array}{l}\text { Percentage of } \\
\text { glucose-C as: }\end{array}$} & \multirow[b]{2}{*}{ Reference } \\
\hline & & & Lactate & $\mathrm{CO}_{2}$ & \\
\hline Mouse thymus & $\overline{+}+$ & $\begin{array}{l}15^{*} \\
26^{*}\end{array}$ & $\begin{array}{l}88 \\
90\end{array}$ & $\begin{array}{l}8 \\
6\end{array}$ & Lengle et al. (1978) \\
\hline Rat thymus & $\begin{array}{l}- \\
+\end{array}$ & $\begin{array}{l}24^{*} \\
47^{*}\end{array}$ & $\begin{array}{l}38 \\
57\end{array}$ & $\begin{array}{l}28 \\
21\end{array}$ & Hume et al. (1978) \\
\hline Rat thymus & $\overline{-}+$ & $\begin{array}{l}17^{*} \\
38^{*}\end{array}$ & $\begin{array}{l}56 \\
68\end{array}$ & $\begin{array}{l}27 \\
18\end{array}$ & Brand (1985) \\
\hline Rat lymph node & $\begin{array}{l}- \\
+\end{array}$ & $\begin{array}{l}35 \dagger \\
54 \dagger\end{array}$ & $\begin{array}{r}75 \\
100\end{array}$ & $\begin{array}{l}\text { nd } \\
\text { nd }\end{array}$ & $\begin{array}{l}\text { Ardawi \& Newsholme } \\
\text { (1984) }\end{array}$ \\
\hline Human blood & $\overline{+}+$ & $\begin{array}{l}65 \ddagger \\
90 \ddagger\end{array}$ & $\begin{array}{l}64 \\
77\end{array}$ & $\begin{array}{r}10 \\
9\end{array}$ & Ardawi (1988) \\
\hline Rat spleen & $\begin{array}{l}- \\
+\end{array}$ & $\begin{array}{r}97^{*} \\
126^{*}\end{array}$ & $\begin{array}{l}48 \\
53\end{array}$ & $\begin{array}{l}10 \\
11\end{array}$ & $\begin{array}{l}\text { O'Rourke \& Rider } \\
\text { (1989) }\end{array}$ \\
\hline Rat spleen & - & $320^{*}$ & 25 & 13 & Wu et al. (1991) \\
\hline Mouse peritoneum & - & 340 里 & 94 & nd & Newsholme et al. (1987) \\
\hline Mouse peritoneum & - & $460 \ddagger$ & 95 & nd & $\begin{array}{l}\text { Newsholme \& Newsholme } \\
\quad \text { (1989) }\end{array}$ \\
\hline
\end{tabular}

Con A, concanavalin A; -, absent; +, present; nd, not determined.

* $\mu \mathrm{mol} / \mathrm{h}$ per $10^{10}$ cells.

$\dagger \mu \mathrm{mol} / \mathrm{h}$ per $\mathrm{g}$ dry wt.

$\ddagger \mathrm{nmol} / \mathrm{h}$ per mg protein.

the in vitro findings. Before surgery the spleen took up glucose and lactate and released glutamine and $\mathrm{NH}_{3}$. After surgery the rate of glucose uptake by the spleen increased by up to 4-fold and there was a net release of lactate; also the spleen took up glutamine and the rate of $\mathrm{NH}_{3}$ release increased by up to 7-fold.

\section{Ketone bodies}

Ketone bodies (acetoacetic and $\beta$-hydroxybutyric acids) can be utilized (and oxidized) by lymphocytes (Hume et al. 1978; Ardawi \& Newsholme, 1984; O'Rourke \& Rider, 1989). Con A stimulation does not affect the rate of ketone-body utilization by lymphocytes (Hume et al. 1978; Ardawi \& Newsholme, 1984), nor does it affect the rate of ketone-body oxidation (Ardawi \& Newsholme, 1984). Starvation of rats for $48 \mathrm{~h}$ does not result in an increase in the rate of ketone-body utilization by isolated lymphocytes (Ardawi \& Newsholme, 1984); this is in contrast to the effect of starvation on ketonebody utilization by tissues such as heart, skeletal muscle, kidney, small intestine and brain. Although murine peritoneal macrophages possess the enzymes of ketone-body metabolism (Newsholme et al. 1986), they do not utilize ketone bodies at a detectable rate (Newsholme et al. 1986, 1987). 
Table 5. Utilization of glutamine by lymphocytes and macrophages

\begin{tabular}{|c|c|c|c|c|c|}
\hline \multirow[b]{2}{*}{ Cell source } & \multirow[b]{2}{*}{ Con A } & \multirow{2}{*}{$\begin{array}{c}\text { Rate of glutamine } \\
\text { utilization }\end{array}$} & \multicolumn{2}{|c|}{$\begin{array}{l}\text { Percentage of } \\
\text { glutamine-C as: }\end{array}$} & \multirow[b]{2}{*}{ Reference } \\
\hline & & & Glutamate & $\mathrm{CO}_{2}$ & \\
\hline Rat spleen & $\begin{array}{l}- \\
+\end{array}$ & $\begin{array}{l}40^{*} \\
60^{*}\end{array}$ & $\begin{array}{l}65 \\
56\end{array}$ & $\begin{array}{l}11 \\
11\end{array}$ & O'Rourke \& Rider (1989) \\
\hline Rat thymus & $\begin{array}{l}- \\
+\end{array}$ & $\begin{array}{r}30^{*} \\
220^{*}\end{array}$ & $\begin{array}{l}47 \\
65\end{array}$ & $\begin{array}{l}21 \\
11\end{array}$ & Brand (1985) \\
\hline Rat lymph node & $\begin{array}{l}- \\
+\end{array}$ & $\begin{array}{l}160 \dagger \\
240 \dagger\end{array}$ & $\begin{array}{l}71 \\
46\end{array}$ & $\begin{array}{l}\text { nd } \\
\text { nd }\end{array}$ & Ardawi \& Newsholme (1983) \\
\hline Human blood & $\begin{array}{l}- \\
+\end{array}$ & $\begin{array}{l}190 \ddagger \\
270 \ddagger\end{array}$ & $\begin{array}{l}44 \\
31\end{array}$ & $\begin{array}{l}21 \\
23\end{array}$ & Ardawi (1988) \\
\hline Rat thymus & $\overline{+}$ & $\begin{array}{r}30^{*} \\
290^{*}\end{array}$ & $\begin{array}{l}47 \\
68\end{array}$ & $\begin{array}{r}11 \\
5\end{array}$ & Brand et al. (1989) \\
\hline T-lymphoblast line & - & $270^{*}$ & 58 & 6 & Brand et al. (1989) \\
\hline B-lymphoblast line & - & $680^{*}$ & 70 & 6 & Brand et al. (1989) \\
\hline Mouse peritoneum & - & $90 \ddagger$ & 20 & 5 & $\begin{array}{l}\text { Newsholme \& Newsholme } \\
\text { (1989) }\end{array}$ \\
\hline Mouse peritoneum & - & $190 \ddagger$ & nd & nd & Newsholme et al. (1987) \\
\hline
\end{tabular}

Con A, concanavalin A; - , absent; +, present; nd, not determined.

* $\mu \mathrm{mol} / \mathrm{h}$ per $10^{10}$ cells.

$\dagger \mu \mathrm{mol} / \mathrm{h}$ per g dry wt.

$\ddagger \mathrm{nmol} / \mathrm{h}$ per $\mathrm{mg}$ protein.

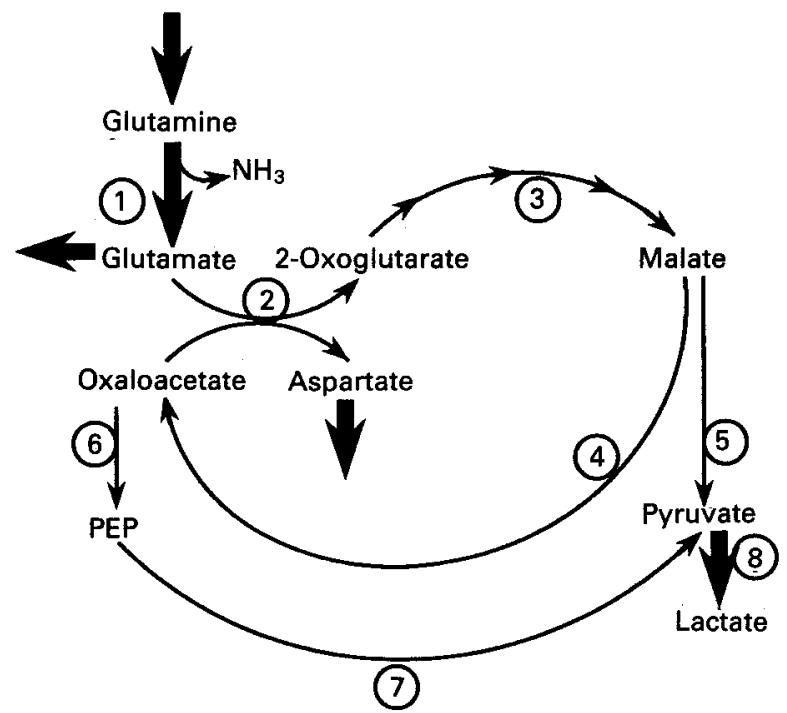

Fig. 1. The pathway of glucose and glutamine metabolism in lymphocytes and macrophages. Enzymes are indicated as: 1, glutaminase $(E C 3.5 .1 .2) ; 2$, aspartate aminotransferase $(E C 2.6 .1 .1)$; 3, enzymes of the second half of the Krebs' cycle; 4, malate dehydrogenase (NAD ${ }^{+}$-linked; $E C$ 1.1.1.37); 5, malic enzyme (NADP ${ }^{+}$. linked; $E C$ 1.1.1.40); 6, phosphoenolpyruvate carboxykinase ( $E C$ 1.1.1.49); 7, pyruvate kinase $(E C 2.7 .1 .40)$; 8, lactate dehydrogenase (EC 1.1.1.2); PEP, phosphoenolpyruvate. 


\section{Fatty acids}

Until the recent work of Yaqoob (1993), studies of fatty acid oxidation by cells of the immune system were restricted to investigating oleic acid. Ardawi \& Newsholme (1984) reported that incubated rat-lymph-node lymphocytes utilize oleic acid at a rate of approximately $34 \mu \mathrm{mol} / \mathrm{h}$ per $\mathrm{g}$ dry weight; macrophages also utilize fatty acids (Mahoney et al. 1977; Lokesh \& Wrann, 1984; Newsholme et al. 1987; Newsholme \& Newsholme, 1989; Calder et al. 1990). Some of the oleic acid used by lymphocytes and macrophages in vitro is oxidized (Lengle et al. 1978; Ardawi \& Newsholme, 1984; Newsholme et al. 1987; Newsholme \& Newsholme, 1989). Ardawi \& Newsholme (1984) reported that the proportion of oleic acid which is completely oxidized to $\mathrm{CO}_{2}$ is only about $1 \%$ of the total utilized by isolated mesenteric-lymph-node lymphocytes incubated for $60 \mathrm{~min}$ and Newsholme \& Newsholme (1989) calculated that for peritoneal macrophages cultured for $80 \mathrm{~h} 25 \%$ of the utilized oleic acid is oxidized; in these conditions most of the fatty acid utilized is incorporated into phospholipids and triacylglycerols (Ardawi \& Newsholme, 1984; Lokesh \& Wrann, 1984; Newsholme \& Newsholme, 1989; Calder et al. 1994a). Despite the low rate of oleic acid oxidation, it was calculated that fatty acid oxidation contributes more than $30 \%$ to the $\mathrm{O}_{2}$ consumption of isolated lymphocytes (Ardawi \& Newsholme, 1985). Mitogenic stimulation of lymphocytes does not increase the rates of utilization or oxidation of oleic acid in short-term incubations (Ardawi \& Newsholme, 1984).

Recently, Yaqoob (1993) compared the rates of oxidation of palmitic, oleic, linoleic and arachidonic acids by rat-lymph-node lymphocytes in short-term $(1 \mathrm{~h})$ incubations. At physiological fatty acid concentrations the rates of oxidation of these fatty acids were in the range $0 \cdot 5-2 \mathrm{nmol} / \mathrm{h}$ per $\mathrm{mg}$ protein; palmitic and oleic acids were oxidized at a greater rate than linoleic and arachidonic acids (Yaqoob et al. 1994a). Mitogenic stimulation of the cells with Con A did not significantly enhance the rate of oxidation of any of the fatty acids (Yaqoob, 1993; Yaqoob et al. 1994a). Although fatty acids are used as fuels by lymphocytes, their oxidation does not appear to be crucial for lymphocyte function: inhibition of fatty acid oxidation does not affect the ability of lymphocytes to proliferate in response to mitogens (Yaqoob et al. 1994a).

It is known that macrophages produce and secrete lipoprotein lipase ( $E C$ 3.1.1.34; Khoo et al. 1981; Chait et al. 1982; Mahoney et al. 1982; Stray et al. 1990) and also contain a 'hormone-sensitive' triacylglycerol lipase (EC 3.1.1.3; Goldberg \& Khoo, 1990; Small et al. 1991). As a result, these cells have the capacity to utilize the fatty acid component of circulating triacylglycerols and of triacylglycerols stored intracellularly. Recently, it was reported that lymphocytes from various sources possess lipoprotein lipase activity and that lymphocytes are able to hydrolyse triacylglycerols added to culture medium (Calder et al. 1994b).

\section{Interactions between different fuels}

In tissues such as heart and skeletal muscle, lipid fuels (fatty acids and ketone bodies) have the ability to suppress the utilization of carbohydrate (i.e. glucose) as a fuel. There have been several studies of the interactions between the different fuels of cells of the immune system.

The marked stimulation of the rates of glucose utilization and lactate production caused by Con A are still observed in the presence of acetoacetic acid (Hume et al. 1978; 
Ardawi \& Newsholme, 1984) or $\beta$-hydroxybutyric acid (Ardawi \& Newsholme, 1984); this suggests that inhibition of glucose utilization by ketone bodies, which is an important glucose-sparing mechanism in the heart, skeletal muscles and brain, does not occur in lymphocytes. Furthermore, it has been shown that ketone bodies cannot replace glucose as a fuel for lymphocyte proliferation in vitro (Ardawi \& Newsholme, 1984).

Lengle et al. (1978) reported that oleic acid at concentrations of 100 and $500 \mu \mathrm{M}$ did not affect the rate of glucose utilization by mouse thymocytes cultured for $24 \mathrm{~h}$; the production of $\mathrm{CO}_{2}$ from glucose was significantly decreased by oleic acid, although this represented less than $10 \%$ of the fate of glucose- $\mathrm{C}$ in cells incubated in the absence of fatty acid (Lengle et al. 1978). The rates of glucose utilization and lactate production by rat-lymph-node lymphocytes incubated for $1 \mathrm{~h}$ were unaffected by the presence of oleic acid (Ardawi \& Newsholme, 1984). Similarly, the rates of glucose utilization, glutamine utilization and lactate production by murine peritoneal macrophages cultured for up to $80 \mathrm{~h}$ were unchanged in the presence of $300 \mu \mathrm{m}$-oleic acid (Newsholme \& Newsholme, 1989). These observations indicate that, in cells of the immune system, fatty acids do not suppress the utilization of the two key fuels, glucose and glutamine.

The rates of utilization of both glucose and glutamine by resting rat-lymph-node or human-blood lymphocytes were higher if both fuels were present together in a $60 \mathrm{~min}$ incubation, than if each fuel was used alone (Ardawi \& Newsholme, 1983; Ardawi, 1988); the rates of formation of glutamate, alanine, aspartate and lactate were also greater but the rate of $\mathrm{NH}_{3}$ production was no greater than if glutamine was incubated with the cells alone (Ardawi \& Newsholme, 1983). In contrast, the rates of glucose and glutamine utilization by mouse peritoneal macrophages were decreased if both fuels were present together during a $60 \mathrm{~min}$ incubation, than if each fuel was used alone (Newsholme et al. 1987). However, when macrophages were cultured for a longer period $(23 \mathrm{~h})$ it was found that the rate of glucose utilization increased if glutamine was also present, whereas the rate of glutamine utilization decreased if glucose was also present (Newsholme \& Newsholme, 1989). The differences between these observations are probably a result of the different experimental conditions used (for example, modified phosphate-buffered saline $(9 \mathrm{~g} \mathrm{NaCl} / \mathrm{l})$ in the short-term incubations and culture medium in longer incubations). However, these observations do indicate the complex nature of the interactions between the key fuels and that these interactions may be different in different cell types.

Addition of glucose to the culture medium of Con A-stimulated rat thymocytes has been shown to decrease the rates of glutamine utilization (by $37 \%$ ) and of glutamate, aspartate, $\mathrm{NH}_{3}$ and $\mathrm{CO}_{2}$ formation from glutamine (Brand, 1985; Brand et al. 1989). In contrast, there are reports that addition of glucose to proliferating rat thymocytes, splenocytes or lymph-node lymphocytes does not affect the rates of production of glutamate or $\mathrm{NH}_{3}$ from glutamine; the rate of production of aspartate was decreased by inclusion of glucose in the culture medium (Wu et al. 1991). Addition of glutamine to the culture medium of Con A-stimulated rat splenocytes increased the rates of glucose utilization and of the formation of lactate and $\mathrm{CO}_{2}$ from glucose (O'Rourke \& Rider, 1989).

\section{Relative contributions of different fuels to ATP generation}

The relative contribution of different fuels to overall ATP generation in some immune system cells has been calculated. Newsholme \& Newsholme (1989) calculated that catabolism of glucose, glutamine and oleic acid contribute 54,24 and $22 \%$ respectively of 
the ATP generated by cultured murine peritoneal macrophages, while Spolarics et al. (1991) calculated that for rat Kupffer cells the catabolism of glucose, glutamine, lactate and palmitic acid contribute $20,35,15$ and $30 \%$ respectively of ATP generated.

\section{AN EXPLANATION FOR HIGH RATES OF GLUCOSE AND GLUTAMINE UTILIZATION}

Lymphocytes and macrophages utilize both glucose and glutamine at high rates in vitro (see p. 71). These cells have widely differing biological properties; lymphocytes have the capacity for rapid cell division, whereas macrophages are terminally differentiated and have lost the capacity for cell division. It has been considered that the principal role of these high rates of utilization is the provision of energy. However, neither glucose nor glutamine is fully oxidized by these cells; almost all the glucose is converted to lactate (Table 4) and almost all the glutamine is converted to glutamate, lactate and aspartate (Table 5). Complete oxidation of glucose and glutamine to $\mathrm{CO}_{2}$ would yield much more energy than glycolysis and glutaminolysis do. Therefore, if energy generation from glucose and glutamine was important in these cells it would be expected that more of the $\mathrm{C}$ would be fully oxidized via the Krebs' cycle, the enzymes of which are present (Table 1). Thus, it seems that the non-oxidative metabolism of glucose and glutamine must have a role other than energy provision. A further suggestion for the high rates of glucose and glutamine utilization is that they provide intermediates for the biosynthesis of purine and pyrimidine nucleotides which are required for the synthesis of DNA and mRNA by these cells. However, the rate of, and the maximum capacity for, the synthesis of pyrimidine nucleotides by lymphocytes is very small compared with the rates at which glucose and glutamine are utilized by these cells (Szondy \& Newsholme, 1989). A further hypothesis suggests that the high rates of glycolysis and glutaminolysis are important to provide optimal conditions for the precise regulation of the rates of synthesis of important molecules, for example purine and pyrimidine nucleotides at specific times of the lymphocyte cell cycle. This hypothesis is based on 'metabolic control logic', and is described fully elsewhere (Newsholme et al. 1985, 1989).

Glucose provides intermediates for the synthesis of DNA, RNA and phospholipids, while glutamine provides intermediates for the synthesis of DNA, RNA, glucosamine and $\mathrm{NAD}^{+}$. Thus, the pathways of glucose and glutamine utilization are branched to allow intermediates to be directed along different biosynthetic pathways (Fig. 2). When a particular product is required the flux through the pathway leading to that product will be increased by a metabolic regulator. This has the effect of decreasing the concentration of the metabolic intermediate in the main pathway, thus opposing the effect of stimulation of the biosynthetic pathway. This effect is overcome if the flux through the main pathway (in this case glycolysis and glutaminolysis) is much greater than the flux through the pathways which branch from it. As such, maintenance of high rates of glycolysis and glutaminolysis are seen as a device to allow intermediates to be 'tapped off' at the precise rate required for biosynthesis (Newsholme et al. 1985, 1989).

\section{IMMUNOMODULATORY EFFECTS OF GLUTAMINE}

More than 20 years ago it was observed that asparaginase (EC 3.5.1.1), glutaminase or glutamine antagonists inhibit lymphocyte proliferation in vitro (Hersh, 1970; Simberkoff \& Thomas, 1970; Hersh \& Brown, 1971). Furthermore, asparaginase treatment of 


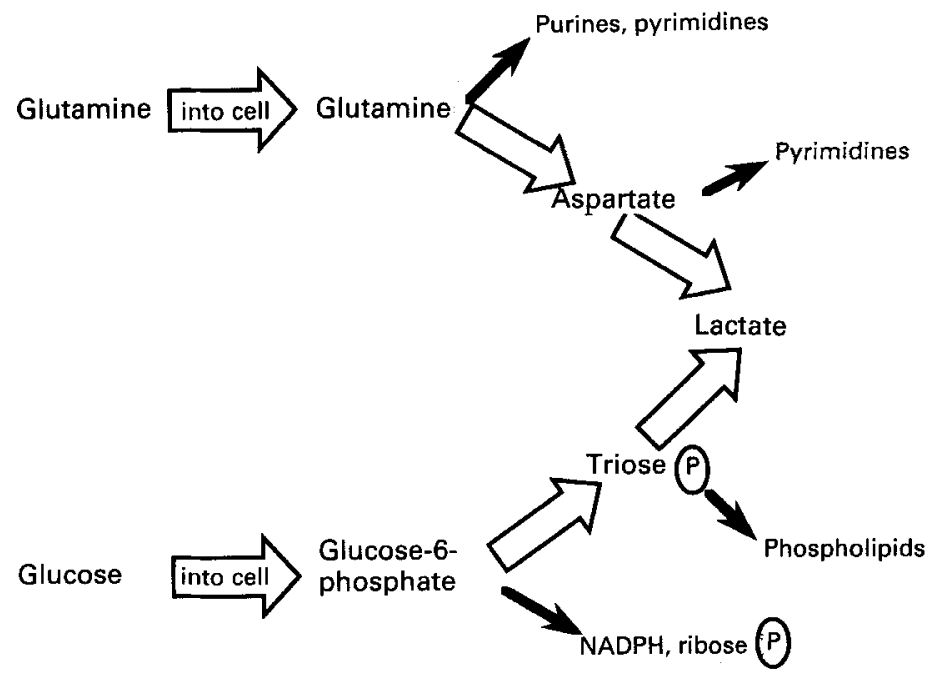

Fig. 2. Branched pathways of glycolysis and glutaminolysis in lymphocytes and macrophages. Glutamine provides nitrogen for both purine and pyrimidine rings and carbon for the pyrimidine ring. Glucose-6phosphate is the substrate for the pentose phosphate pathway which provides both ribose-5-phosphate and NADPH for nucleotide biosynthesis. Triose phosphates provide glycerol-3-phosphate for phospholipid syntheis. (P), phosphate.

animals leads to immunosuppression (Brambilla et al. 1970; Chakrabarty \& Friedman, 1970; Ashworth \& MacLennan, 1974; Kafkewitz \& Bendich, 1983). The immunosuppressive effect of asparaginase was shown to be due to its ability to hydrolyse glutamine (Ashworth \& MacLennan, 1974; Durden \& Distasio, 1981; Kafkewitz \& Bendich, 1983). These observations suggest that a supply of glutamine is required for the immune system to function. Indeed, a number of immune cell functions tested in vitro have been found to be dependent on the provision of glutamine over the physiological concentration range; these include mitogen-stimulated lymphocyte proliferation (Ardawi \& Newsholme, 1983; Szondy \& Newsholme, 1989; Griffiths \& Keast, 1990; Parry-Billings et al. 1990), production of IL-1 by macrophages (Wallace \& Keast, 1992) and IL-2 by lymphocytes (Calder \& Newsholme, 1992a), RNA synthesis by macrophages (Wallace \& Keast, 1992) and lymphocytes (Calder, 1994) and phagocytic activity of macrophages (Parry-Billings et al. 1990; Wallace \& Keast, 1992). The role of glutamine as a fuel for the immune system has been reviewed recently (Calder, 1994).

In support of the notion that supply of glutamine is required for optimal immune function, it has been found that plasma glutamine concentrations in man are lowered in states often associated with immunosuppression, for example, in sepsis (Roth et al. 1982), following surgery (Lund et al. 1986; Parry-Billings et al. 1992a; Castell et al. 1993), burns (Parry-Billings et al. 1990), injury (Askanazi et al. 1980) and endurance exercise (Parry-Billings et al. 1993) and in the overtrained athlete (Parry-Billings et al. 1992b).

\section{IMMUNOMODULATORY EFFECTS OF FATTY ACIDS}

Polyunsaturated fatty acids (PUFA) such as dihomo- $\gamma$-linolenic, arachidonic, eicosapentaenoic and docosahexaenoic acids can modulate immune cell functions by 
modulating the synthesis of immunoregulatory eicosanoids (for review, see Hwang, 1989). In addition, a number of in vitro studies indicate that fatty acids have immunomodulatory functions which are independent of the synthesis of eicosanoids. For example, unsaturated fatty acids inhibit mitogen-stimulated proliferation of lymphocytes isolated from rat lymph nodes (Calder et al. 1991), spleen (Tsang et al. 1977) and lymphatic duct (Calder et al. 1992), from mouse spleen (Tsang et al. 1977; Buttke, 1984), from pig lymph nodes (Tsang et al. 1977) or from human peripheral blood (Weyman et al. 1977; Calder \& Newsholme, 1992b; Soyland et al. 1993). The $n-3$ PUFA, eicosapentaenoic acid, is the most potent inhibitor of lymphocyte proliferation, although other $n-3$ PUFA, such as docosahexaenoic and $\alpha$-linolenic acids, and $n-6$ PUFA, such as arachidonic and linoleic acids, also cause marked inhibition. Saturated fatty acids and the n-9 monounsaturated fatty acid, oleic acid, have less effect than PUFA. It has been suggested that the inhibitory effects of PUFA on lymphocyte proliferation are due to the synthesis of inhibitory eicosanoids or to peroxidation of the fatty acids. However, the inhibitory effect of unsaturated fatty acids is independent of both eicosanoid synthesis (Santoli et al. 1990; Calder et al. 1992; Soyland et al. 1993) and lipid peroxidation (Calder \& Newsholme, 1993; Soyland et al. 1993). It is speculated that the effects of fatty acids are mediated through changes in the fatty acid composition of membrane phospholipids, perhaps via changes in plasma membrane fluidity (Calder et al. 1994a). Unsaturated fatty acids also suppress the production of the immunoregulatory cytokine IL-2 by mitogenstimulated rat and human lymphocytes in vitro (Calder \& Newsholme, 1992b,c) and suppress the appearance of some activation markers on the lymphocyte cell surface (Calder \& Newsholme, 1992c). In addition, some unsaturated fatty acids inhibit natural killer cell activity (Yamashita et al. 1991), antigen presentation (Fujikawa et al. 1991) and monokine production (Watson et al. 1990) in vitro. The in vitro effects of fatty acids on immune cell functions have been recently reviewed (Yaqoob \& Calder, 1993).

The in vitro effects suggest that diets containing unsaturated fatty acids may have immunosuppressive properties. Indeed, it has recently been shown that feeding rats diets rich in olive oil (which contains a high proportion of oleic acid), evening primrose (Oenothera biennis) oil (which contains a high proportion of linoleic acid and some $\gamma$-linolenic acid) or fish oil (which contains a high proportion of $n-3$ PUFA) results in suppression of mitogen-stimulated lymphocyte proliferation (Yaqoob et al. 1994b) and natural killer cell activity (Yaqoob et al. 1994c), subsequently tested in vitro. Furthermore, supplementation of the human diet with encapsulated fish oils results in inhibition of peripheral blood lymphocyte proliferation and IL-2 production (Meydani et al. 1991) and inhibition of IL-1, IL- 6 and tumour necrosis factor production by peripheral blood mononuclear cells (Endres et al. 1989).

\section{CONCLUDING REMARKS}

Almost all studies of fuel utilization by cells of the immune system have been performed using the cells in culture. These studies indicate that lymphocytes and macrophages are able to utilize glucose, glutamine and fatty acids (and also ketone bodies in the case of lymphocytes) as energy sources; complete oxidation of glucose and glutamine is limited and consequently fatty acid oxidation may provide a significant proportion of the energy requirement of these cells. The interaction between different fuels has been investigated to only a limited extent and the experimental results obtained are often contradictory. 
Given the importance of nutrition of the immune system in various clinical settings, there is surprisingly little information about the factors which govern the selection of different fuels by the immune system. There is no information about the roles of different fuels amongst different lymphocyte subsets such as B-cells, helper T-cells, suppressor T-cells and natural killer cells. It is apparent, however, that fuels such as glucose, glutamine and fatty acids play a role in modulating the functions of cells of the immune system.

\section{REFERENCES}

Ardawi, M. S. M. (1988). Glutamine and glucose metabolism in human peripheral lymphocytes. Metabolism 37, 99-103.

Ardawi, M. S. M. \& Newsholme, E. A. (1982). Maximum activities of some enzymes of glycolysis, the tricarboxylic acid cycle and ketone-body and glutamine utilisation pathways in lymphocytes of the rat. Biochemical Journal 208, 743-748.

Ardawi, M. S. M. \& Newsholme, E. A. (1983). Glutamine metabolism in lymphocytes of the rat. Biochemical Journal 212, 835-842.

Ardawi, M. S. M. \& Newsholme, E. A. (1984). Metabolism of ketone bodies, oleate and glucose in lymphocytes of the rat. Biochemical Journal 221, 255-260.

Ardawi, M. S. M. \& Newsholme, E. A. (1985). Metabolism in lymphocytes and its importance in the immune response. Essays in Biochemistry 21, 1-44.

Ashworth, L. A. E. \& MacLennan, A. P. (1974). Comparison of L-asparaginases from Escherichia coli and Erwinia carotovora and immunosuppressants. Cancer Research 34, 1353-1359.

Askanazi, J., Carpentier, Y. A., Michelsen, C. B., Elwyn, D. H., Furst, P., Kantrowitz, L. R., Gump, F. E. \& Kinney, J. M. (1980). Muscle and plasma amino acids following injury. Annals of Surgery 192, 78-85.

Brambilla, G., Pardodi, S., Cavanna, M., Caraceni, C. E. \& Baldini, L. (1970). The immunodepressive activity of $E$. coli L-asparaginase in some transplant systems. Cancer Research 30, 2665-2670.

Brand, K. (1985). Glutamine and glucose metabolism during thymocyte proliferation. Biochemical Journal 228, 353-361.

Brand, K., Fek1, W., von Hintzenstern, J., Langer, K., Luppa, P. \& Schoerner, C. (1989). Metabolism of glutamine in lymphocytes. Metabolism 8, 29-33.

Bustos, R. \& Sobrino, F. (1989). Control of fructose 2,6-biphosphate levels in rat macrophages by glucose and phorbol ester. FEBS Letters 251, 143-146.

Buttke, T. M. (1984). Inhibition of lymphocyte proliferation by free fatty acids. Immunology $\mathbf{5 3}, 235-242$.

Calder, P. C. (1994). Glutamine and the immune system. Clinical Nutrition 13, 2-8.

Calder, P. C., Bevan, S. J. \& Newsholme, E. A. (1992). The inhibition of T-lymphocyte proliferation by fatty acids is via an eicosanoid-independent mechanism. Immunology $75,108-115$.

Calder, P. C., Bond, J. A., Bevan, S. J., Hunt, S. V. \& Newsholme, E. A. (1991). Effect of fatty acids on the proliferation of concanavalin A-stimulated rat lymph node lymphocytes. International Journal of Biochemistry 23, 579-588.

Calder, P. C., Bond, J. A., Harvey, D. J., Gordon, S. \& Newsholme, E. A. (1990). Uptake and incorporation of saturated and unsaturated fatty acids into macrophage lipids and their effect upon macrophage adhesion and phagocytosis. Biochemical Journal 269, 807-814.

Calder, P. C. \& Newsholme, E. A. (1992a). Glutamine promotes interleukin-2 production by concanavalin A-stimulated lymphocytes. Proceedings of the Nutrition Society 51, 105A.

Calder, P. C. \& Newsholme, E. A. (1992b). Polyunsaturated fatty acids suppress human peripheral blood lymphocyte proliferation and interleukin-2 production. Clinical Science 82, 695-700.

Calder, P. C. \& Newsholme, E. A. (1992c). Unsaturated fatty acids suppress interleukin-2 production and transferrin receptor expression by concanavalin A-stimulated rat lymphocytes. Mediators of Inflammation $1,107-112$.

Calder, P. C. \& Newsholme, E. A. (1993). Influence of antioxidant vitamins on fatty acid inhibition of lymphocyte proliferation. Biochemistry and Molecular Biology International 29, 175-183.

Calder, P. C., Yaqoob, P., Harvey, D. J., Watts, A. \& Newsholme, E. A. (1994a). The incorporation of fatty acids by lymphocytes and the effect on fatty acid composition and membrane fluidity. Biochemical Journal 300, 509-518. 
Calder, P. C., Yaqoob, P. \& Newsholme, E. A. (1994b). Triacylglycerol metabolism by lymphocytes and the effect of triacylglycerols on lymphocyte proliferation. Biochemical Journal 298, 605-611.

Castell, L. M., Powell, H., Parry-Billings, M. \& Newsholme, E. A. (1993). The effect of surgery on plasma glutamine concentrations. Proceedings of the Nutrition Society 52, $70 \mathrm{~A}$.

Chait, A., Iverius, P.-H. \& Brunzell, J. D. (1982). Lipoprotein lipase secretion by human monocyte-derived macrophages. Journal of Clinical Investigation 69, 490-493.

Chakrabarty, A. K. \& Friedman, H. (1970). L-Asparaginase-induced immunosuppression: effects on antibodyforming cells and serum titers. Science 167, 869-870.

Curi, R., Newsholme, P. \& Newsholme, E. A. (1986). Intracellular distribution of some enzymes of the glutamine utilisation pathway in rat lymphocytes. Biochemical and Biophysical Research Communications 138, 318-322.

Curi, R., Williams, J. F. \& Newsholme, E. A. (1989a). Pyruvate metabolism by lymphocytes: Evidence for an additional ketogenic tissue. Biochemistry International 19, 755-767.

Curi, R., Williams, J, F. \& Newsholme, E. A. (1989b). Formation of ketone bodies by resting lymphocytes. International Journal of Biochemistry 21, 1133-1136.

Deutz, N. E. P., Reijven, P. L. M., Athanasas, G. \& Soeters, P. B. (1992). Post-operative changes in hepatic, intestinal, splenic and muscle fluxes of amino acids and ammonia in pigs. Clinical Science 83, 607-614.

Durden, D. L. \& Distasio, J. A. (1981). Characterisation of the effects of asparaginase from Escherichia coli and a glutaminase-free asparaginase from Vibrio succinogenes on specific cell-mediated cytotoxicity. International Journal of Cancer 27, 59-65.

Endres, S., Ghorbani, R., Kelley, V. E., Georgilis, K., Lonnemann, G., Van Der Meer, J. M. W., Cannon, J. G., Rogers, T. S., Klempner, M. S., Weber, P. C., Schaeffer, E. J., Wolff, S. M. \& Dinarello, C. A. (1989). The effect of dietary supplementation with $n-3$ polyunsaturated fatty acids on the synthesis of interleukin-1 and tumor necrosis factor by mononuclear cells. New England Journal of Medicine 320, 265-271.

Fujikawa, M., Yamashita, N., Yamazaki, K., Sugiyama, E., Suzuki, H. \& Hamazaki, T. (1992), Eicosapentaenoic acid inhibits antigen-presenting cell function of murine splenocytes. Immunology 75, 330-335.

Goldberg, D. I. \& Khoo, J. C. (1990). Secretion of the lysosomal acid triacylglycerol hydrolase precursor by J774 macrophages. Biochimica et Biophysica Acta 960, 200-209.

Griffiths, M. \& Keast, D. (1990). The effect of glutamine on murine splenic leukocyte responses to T and B cell mitogens. Immunology and Cell Biology 68, 405-408.

Hersh, E. M. (1970). L-Glutaminase: suppression of lymphocyte blastogenic responses in vitro. Science 172, 736-738.

Hersh, E. M. \& Brown, B. W. (1971). Inhibition of immune response by glutamine antagonism: effect of azotomycin on lymphocyte blastogenesis. Cancer Research 31, 834-840.

Hume, D. A., Radik, J. L., Ferber, E. \& Weidemann, M. J. (1978). Aerobic glycolysis and lymphocyte transformation. Biochemical Journal 174, 703-709.

Hwang, D. (1989). Essential fatty acids and the immune response. FASEB Journal 2, 2053-2061.

Kafkewitz, D. \& Bendich, A. (1983). Enzyme-induced asparagine and glutamine depletion and immune system dysfunction. American Journal of Clinical Nutrition 37, 1025-1030.

Karnovsky, M. L., Simmons, S., Glass, E. A., Shafer, A. W. \& D'Arcy Hart, P. (1970). Metabolism of macrophages. In Mononuclear Phagocytes, pp. 103-120 [R. van Furth, editor]. Oxford: Blackwell Scientific Publications.

Keast, D. \& Newsholme, E. A. (1990). Effect of mitogens on the maximum activities of hexokinase, lactate dehydrogenase, citrate synthase and glutaminase in rat mesenteric lymph node lymphocytes and splenocytes during the early period of culture. International Journal of Biochemistry 22, 133-136.

Khoo, J. C., Mahoney, E. M. \& Witztum, J. L. (1981). Secretion of lipoprotein lipase by macrophages in culture. Journal of Biological Chemistry 256, 7105-7108.

Lengle, E. E., Gustin, N. C., Gonzalez, F., Menahan, L. A. \& Kemp, R. G. (1978). Energy metabolism in thymic lymphocytes of normal and leukemic AKR mice. Cancer Research 38, 1113-1119.

Lokesh, B. R. \& Wrann, M. (1984). Incorporation of palmitic acid or oleic acid into macrophage membrane lipids exerts differential effects on the function of normal mouse peritoneal macrophages. Biochimica et Biophysica Acta 792, 141-148.

Lund, J., Stjernstrom, H., Bergholm, U., Jorfeldt, L., Vinnars, E. \& Wiklund, L. (1986). The exchange of blood-borne amino acids in the leg during abdominal surgical trauma: effects of glucose infusion. Clinical Science 71, 487-496. 
McKeehan, W. L. (1982). Glycolysis, glutaminolysis and cell proliferation. Cell Biology International Reports 6, 635-650.

Mahoney, E. M., Hamill, A. L., Scott, W. A. \& Cohn, Z. A. (1977). Response of endocytosis to altered fatty acyl composition of macrophage phospholipids. Proceedings of the National Academy of Sciences USA 74, 4895-4899.

Mahoney, E. M., Khoo, J. C. \& Steinberg, D. (1982). Lipoprotein lipase secretion by human monocytes and rabbit alveolar macrophages in culture. Proceedings of the National Acaderny of Sciences USA 79, 1639-1642.

Meydani, S. N., Endres, S.,-Woods, M. M., Goldin, B. R., Soo, C., Morrill-Labrode, A., Dinarello, C. \& Gorbach, S. L. (1991). Oral (n-3) fatty acid supplementation suppresses cytokine production and lymphocyte proliferation: comparison between young and older women. Journal of Nutrition 121, 547-555.

Newsholme, E. A., Crabtree, B. \& Ardawi, M. S. M. (1985). The role of high rates of glycolysis and glutamine utilisation in rapidly dividing cells. Bioscience Reports 5, 393-400.

Newsholme, E. A., Newsholme, P., Curi, R., Crabtree, B. \& Ardawi, M. S. M. (1989). Glutamine metabolism in different tissues - Its physiological and pathological importance. In Perspectives in Clinical Nutrition, $\mathrm{pp}$. 71-98 [J. M. Kinney and P. R. Borum, editors]. Baltimore: Urban \& Schwarzenberg.

Newsholme, P., Curi, R., Gordon, S. \& Newsholme, E. A. (1986). Metabolism of glucose, glutamine, long-chain fatty acids and ketone bodies by murine macrophages. Biochemical Journal 239, 121-125.

Newsholme, P., Gordon, S. \& Newsholme, E. A. (1987). Rates of utilisation and fates of glucose, glutamine, pyruvate, fatty acids and ketone bodies by mouse macrophages. Biochemical Journal 242, 631-636.

Newsholme, P. \& Newsholme, E. A. (1989). Rates of utilisation of glucose, glutamine and oleate and formation of end products by mouse peritoneal macrophages in culture. Biochemical Journal 261, 211-218.

O'Rourke, A. M. \& Rider, L. C. (1989). Glucose, glutamine and ketone body utilisation by resting and concanavalin A activated rat splenic lymphocytes. Biochimica et Biophysica Acta 1010, 342-345.

Parry-Billings, M., Baigrie, R. J., Lamont, P. M., Morris, P. J. \& Newsholme, E. A. (1992a). Effects of major and minor surgery on plasma glutamine and cytokine levels. Archives of Surgery 127, 1237-1240.

Parry-Billings, M., Budgett, R., Koutedakis, Y., Blomstrand, E., Brooks, S., Williams, C., Calder, P. C., Pilling, S., Baigrie, R. \& Newsholme, E. A. (1992b). Plasma amino acid concentrations in the overtraining syndrome: possible effects on the immune system. Medicine and Science in Sports and Exercise 24, 1353-1358.

Parry-Billings, M., Evans, J., Calder, P. C. \& Newsholme, E. A. (1990). Does glutamine contribute to immunosuppression after major burns? Lancet 336, 523-525.

Parry-Billings, M., Matthews, V. J., Newsholme, E. A., Budgett, R. \& Koutedakis, J. (1993). The overtraining syndrome: some biochemical aspects. In Intermittent High Intensity Exercise, pp. 215-225 [D. A. D. Macleod, R. J. Maughan, C. Williams, C. R. Madeley, J. C. M. Sharp and R. W. Nutton, editors]. London: E. \& F. N. Spon.

Roos, D. \& Loos, J. A. (1973). Changes in the carbohydrate metabolism of mitogenically stimulated human peripheral lymphocytes. Experimental Cell Research 77, 127-135.

Roth, E., Funovics, J., Muhlbacher, F., Schemper, M., Mauritz, W., Sporn, P. \& Fritsch, A. (1982). Metabolic disorders in severe abdominal sepsis: glutamine deficiency in skeletal muscle. Clinical Nutrition 1, 25-41.

Santoli, D., Phillips, P. D., Colt, T. L. \& Zurier, R. B. (1990). Suppression of interleukin 2-dependent human $\mathrm{T}$ cell growth in vitro by prostaglandin $\mathrm{E}$ (PGE) and their precursor fatty acids. Journal of Clinical Investigation 85, 424-432.

Simberkoff, M. S. \& Thomas, L. (1970). Reversal by L-glutamine of the inhibition of lymphocyte mitosis caused by E. coli asparaginase. Proceedings of the Society of Experimental Biology 133, 642-643.

Small, C. A., Rogers, M. P., Goodacre, J. A. \& Yeaman, S. J. (1991). Phosphorylation and activation of hormone sensitive lipase in isolated macrophages. FEBS Letters 279, 323-326.

Soyland, E., Nenseter, M. S., Braathen, L. \& Drevon, C. A. (1993). Very long chain $n-3$ and $n-6$ polyunsaturated fatty acids inhibit proliferation of human T-lymphocytes in vitro. European Journal of Clinical Investigation 23, 112-121.

Spolarics, Z., Lang, C. H., Bagby, G, J. \& Spitzer, J. J. (1991). Glutamine and fatty acid oxidation are the main sources of energy in Kupffer and endothelial cells. American Journal of Physiology 261, G185-G190.

Stray, N., Letnes, H. \& Blomhoff, J. P. (1990). Intracellular regulation of lipoprotein lipase in human monocyte-derived macrophages. Biochimica et Biophysica Acta 1045, 280-284.

Szondy, Z. \& Newsholme, E. A. (1989). The effect of glutamine concentration on the activity of carbamoyl-phosphate synthase II and on the incorporation of $\left[{ }^{3} \mathrm{H}\right]$ thymidine into DNA in rat mesenteric lymphocytes stimulated by phytohaemagglutinin. Biochemical Journal 261, 979-983. 
Tsang, W. M., Weyman, C. \& Smith, A. D. (1977). Effect of fatty acid mixtures on phytohaemagglutininstimulated lymphocytes from different species. Biochemical Society Transactions 5, 153-154.

Wallace, C. \& Keast, D. (1992). Glutamine and macrophage function. Metabolism 41, 1016-1020.

Watson, J., Madhok, R., Wijelath, E., Capell, H. A., Gillespie, J., Smith, J. \& Byars, B. L. (1990). Mechanism of action of polyunsaturated fatty acids in rheumatoid arthritis. Biochemical Society Transactions 18, 284-285.

Weyman, C., Morgan, S. J., Belin, J. \& Smith, A. D. (1977). Phytohaemagglutinin stimulation of human lymphocytes: effect of fatty acids on uridine uptake and phosphoglyceride fatty acid profile. Biochimica et Biophysica Acta 496, 155-166.

Wu, G., Field, C. J. \& Marliss, E. B. (1991). Elevated glutamine metabolism in splenocytes from spontaneously diabetic BB rats. Biochemical Journal 274, 49-54.

Yamashita, N., Maruyama, M., Yamazaki, K., Hamazaki, T. \& Yano, S. (1991). Effect of eicosapentaenoic and docosahexaenoic acid on natural killer cell activity in human peripheral blood lymphocytes. Clinical Immunology and Immunopathology 59, 335-345.

Yaqoob, P. (1993). The effects of fatty acids on the composition and functions of lymphocytes. DPhil Thesis, University of Oxford.

Yaqoob, P. \& Calder, P. C. (1993). The effects of fatty acids on lymphocyte functions. International Journal of Biochemistry 25, 1705-1714.

Yaqoob, P., Newsholme, E. A. \& Calder, P. C. (1994a). Fatty acid oxidation by lymphocytes. Biochemical Society Transactions 22, $116 \mathrm{~S}$.

Yaqoob, P., Newsholme, E. A. \& Calder, P. C. (1994b). The effect of dietary lipid manipulation on rat lymphocyte subsets and proliferation. Immunology 82, 603-610.

Yaqoob, P., Newsholme, E. A. \& Calder, P. C. (1994c). Inhibition of natural killer cell activity by dietary lipids. Immunology Letters 41, 241-247. 